\title{
Change Management: An Information Flow Approach
}

Ellen Hoadley, Loyola University of Maryland, USA

Jennifer Lamos, Loyola University of Maryland, USA

\begin{abstract}
Industries use information in common ways to facilitate change initiatives. A review of change management models by John Kotter, Einar Iveroth, Michael Beer, Russel Eisenstat, Bert Spector, Wanda Orlikowski, and J. Hofman were completed. These were then synthesized into a new Information Flow Model. The Information Flow Model focuses on information flow and commonality being the drivers of successful change. This model was validated using three individual interviews with director level or above personnel from differing industries. The interviews did validate the new Information Flow Model and its focus. Additional recommendations for future analyses were provided.
\end{abstract}

Keywords: Change Initiative; Vision; Mission; Information Flow; Project Management; Organizational Culture

\section{INTRODUCTION}

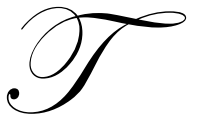

he ability of an organization to respond to changes both internally and externally directly affects whether or not that company will be successful in the marketplace. This relationship is becoming ever more important as the marketplace has globalized. Globalization has been accelerated by advances in technology and information systems. Information is core to all decision making as is the process organizations use to make decisions. This article reflects on the existing models defined for change management to pull out the common themes among them to build a holistic model for use. The cornerstones of the synthesized model are the manner in which information itself flows and the need to have commonality of vision and behavior to support a consistent voice.

\section{Change Management Models}

John Kotter's Eight Step Model for Change

John Kotter, of Harvard Business School, in Leading Change defined an eight step model to address what he found to be the eight reasons why corporate change fails. The premise of his eight step process is that "transformation is 70 to 90 percent leadership and only 10 to 30 percent management." Kotter argues that change leaders should (1) establish a sense of urgency (2) form a powerful coalition (3) create a vision and a strategy to implement it (4) communicate the vision whenever possible (5) empower others to act on the vision by redesigning the organization to remove obstacles to change (6) plan for, create, and celebrate short term wins (7) consolidate short term wins and keep the momentum for change moving, and (8) institutionalize the new approaches into the organizational culture (Kotter).

\section{Einar Iveroth's Commonality Framework for IT-Enabled Change}

Einar Iveroth, a California Management Review and London School of Economics researcher, developed the commonality framework from studying the successful IT-enabled change corporation, Ericsson, a multinational provider of telecommunication equipment. According to Iveroth, Ericcson used a framework for change based on striking a balance between hard and soft factors. Hard factors include technological, economical, and structure issues which are the enablers of change, i.e. the foundation. Soft factors include people, social, and organizational 
issues which are the elements which ultimately make IT-enabled change successful. Analytically, the framework consists of four dimensions of complexity: common ground, common meaning, common interest, and common behavior. The overall point of the framework is that the greater amount of commonality within a change dimension, the greater the likelihood is for change implementation, acceptance, and success (Iveroth).

Table 1: The Commonality Framework (Iveroth)

\begin{tabular}{|l|l|l|l|l|}
\hline \multicolumn{1}{|c|}{$\begin{array}{c}\text { Change } \\
\text { Dimension }\end{array}$} & \multicolumn{1}{|c|}{ Change Activity } & $\begin{array}{c}\text { Role of Change } \\
\text { Agent }\end{array}$ & \multicolumn{1}{c|}{ Uses } & Examples \\
\hline $\begin{array}{l}\text { Common } \\
\text { Ground }\end{array}$ & $\begin{array}{l}\text { Transactional activities; aims } \\
\text { to increase shared } \\
\text { understanding among those } \\
\text { affected by the change }\end{array}$ & Messenger & $\begin{array}{l}\text { Transfer of a change message } \\
\text { between change agent and } \\
\text { change recipient }\end{array}$ & Email, telephone, post \\
\hline $\begin{array}{l}\text { Common } \\
\text { Meaning }\end{array}$ & $\begin{array}{l}\text { Translational activities; aims } \\
\text { to translate change directives } \\
\text { into something that people can } \\
\text { apply to their daily work }\end{array}$ & $\begin{array}{l}\text { Expert and } \\
\text { Translator }\end{array}$ & $\begin{array}{l}\text { Aim at overcoming interpretive } \\
\text { differences between actors } \\
\text { through learning and reflection }\end{array}$ & $\begin{array}{l}\text { Global and local } \\
\text { conferences, } \\
\text { workshops, teaching } \\
\text { and learning activities, } \\
\text { and work-shadowing. }\end{array}$ \\
\hline $\begin{array}{l}\text { Common } \\
\text { Interest }\end{array}$ & $\begin{array}{l}\text { Relational activities; aims to } \\
\text { align interests among various } \\
\text { stakeholders }\end{array}$ & $\begin{array}{l}\text { Negotiator and } \\
\text { Coach }\end{array}$ & $\begin{array}{l}\text { Political activities align } \\
\text { interests by negotiations and } \\
\text { informal relationships. } \\
\text { Supportive activities manage } \\
\text { feelings and emotions and } \\
\text { motive change recipients. }\end{array}$ & $\begin{array}{l}\text { Change agents gain } \\
\text { access to local } \\
\text { company through local } \\
\text { gatekeepers, coaching } \\
\text { sessions, one-to-one } \\
\text { communication }\end{array}$ \\
\hline $\begin{array}{l}\text { Common } \\
\text { Behavior }\end{array}$ & $\begin{array}{l}\text { Stabilizing activities; aims to } \\
\text { secure the recipients' adoption } \\
\text { of an adaptation to the } \\
\text { implemented change, } \\
\text { completed after the IT is } \\
\text { implemented }\end{array}$ & $\begin{array}{l}\text { Observer and } \\
\text { Intervener }\end{array}$ & $\begin{array}{l}\text { Monitoring, communicating, } \\
\text { and intervening actions which } \\
\text { secure long-term and recurrent } \\
\text { behavior aligned to the new IT. }\end{array}$ & $\begin{array}{l}\text { Key Performance } \\
\text { Indicators (KPIs) }\end{array}$ \\
\end{tabular}

\section{Michael Beer, Russel Eisenstat, and Bert Spector's Task Alignment Model for Change}

Beer, Eisenstat, and Spector posit that successful change efforts do not come from top but start at the organization's periphery, i.e. the unit managers. They offer a change model focused on task alignment focused on the work, not abstractions like culture or empowerment. Finally, they believe that senior management's role should be to give general direction. The task alignment model has six steps

1. Mobilize commitment to change through joint diagnosis of business problems, i.e. clearly identify the problem to be addressed.

2. Develop a shared vision of how to organize for competitiveness, i.e. remove barriers of function, hierarchy, titles, and compensation to promote honest information sharing amongst the levels.

3. Foster consensus for the new vision, competence to enact it, and cohesion to advance it, i.e. strong general management is needed to overcome resistance to change and to foster the skills needed to make the new organization work.

4. Spread revitalization to all departments without pushing it from the top, i.e. allow "reinventing the wheel" processes to flesh out the specific roles and responsibility matrices for departments.

5. Institutionalize revitalization through formal policies, systems, and structures after new approach is up and running, i.e. give the process enough time to ensure its success before claiming victory

6. Monitor and adjust strategies in response to problems in the revitalization process, i.e. learn how to learn in a changing competitive environment (Beer) 


\section{Wanda Orlikowski and J. Hofman's Improvisational Model for Change}

According to Orlikowski and Hofman, companies think about change programs in one way but practice them very differently. They claim that corporations think about managing change in terms of planning, defining actions related to that plan, and revising the plan as obstacles are encountered. However, the authors claim that in practice the change process is $a d$ hoc -- do whatever is necessary to implement the change. To this effect, the authors offer an improvisational model recognizing three types of changes: anticipated, emergent, and opportunity-based. The improvisational model (1) has no predefined sequence of events, (2) expects that over time the use of new technology will typically involve a series of the three types of changes, and (3) cannot be charted by management in advance, rather it (and management) recognize that technological change is iterative, unpredictable in path, and evolves from practical experience with the problem (Hofman).

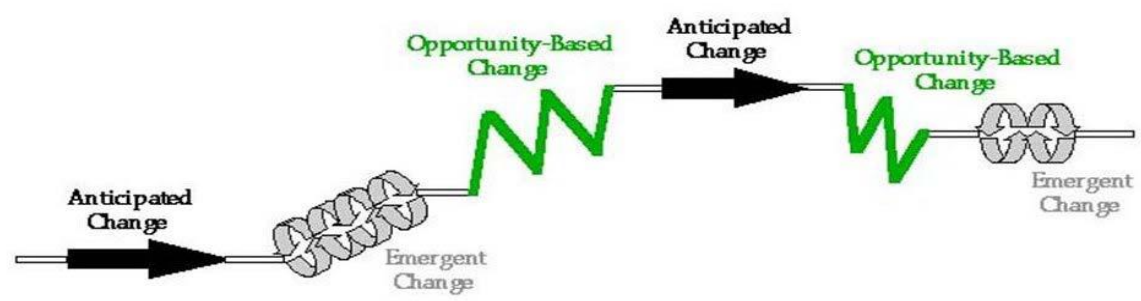

Figure 1: An Improvisational Model of Change Management over Time (Hofman)

\section{Information Flow Model}

Two common denominators in all of the aforementioned models are information flow and consistent behavior. Information flows as part of a continuum - raw data to wisdom as seen in Figure 2 (Ackoff). In addition to a continuum, information flows as part of a hierarchy (Anthony). Information is contextually different at each level of the information triangle (See Figure 3). The operational level contains the greatest volume of data. The tactical level is where the operational data is processed or given meaning and model. Finally, at the strategic level information is used to support decision making and to position the enterprise externally.

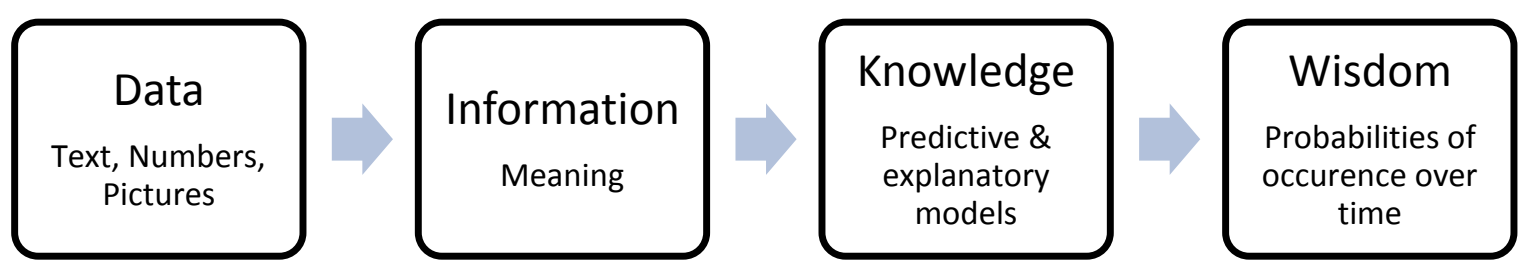

Figure 2: Information Continuum (Ackoff) 


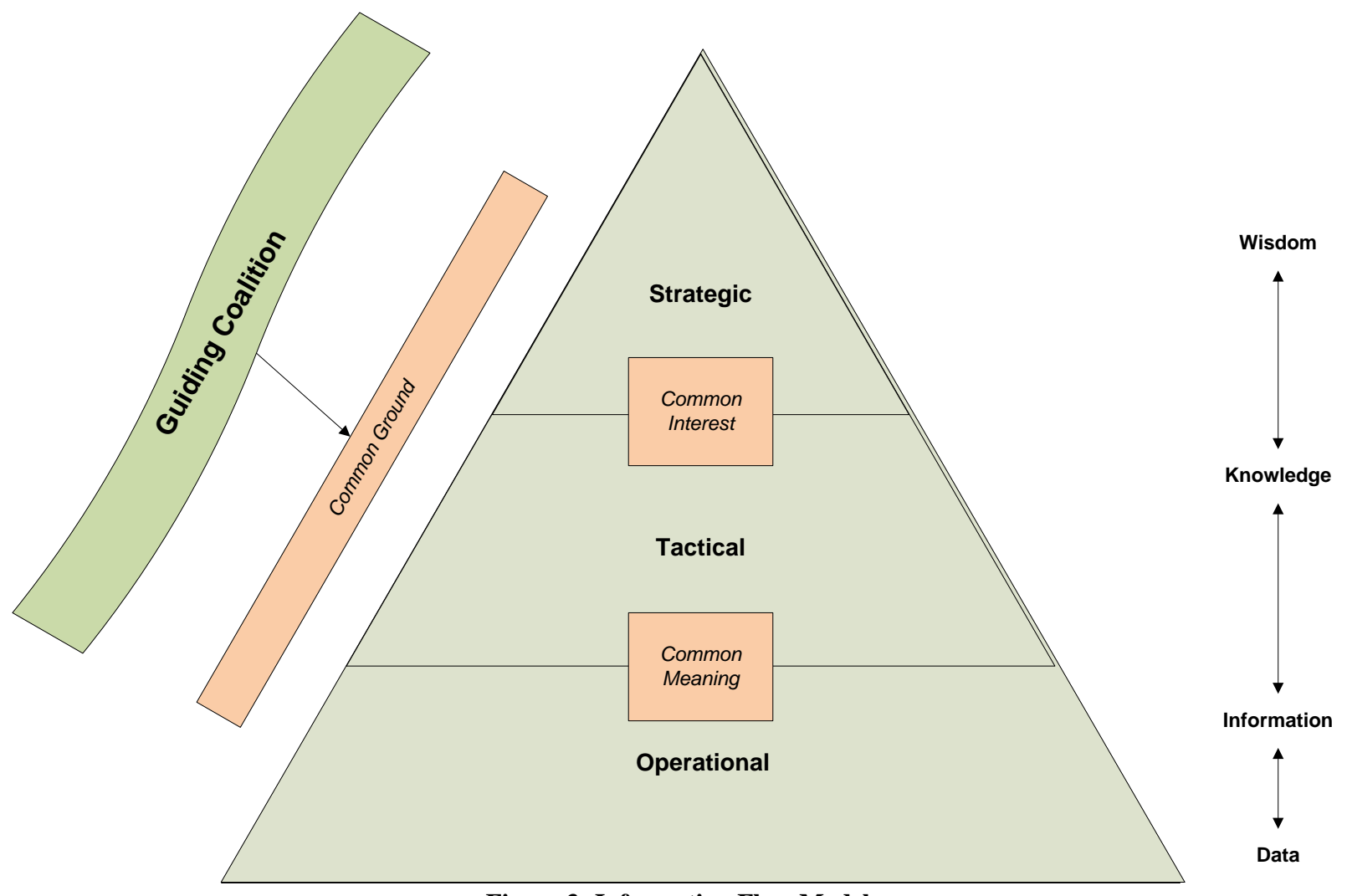

Figure 3: Information Flow Model

The proposed information flow model for change management aligns with the current research in change management mentioned previously and unites the two common denominators into a single conceptual model. The model rests on the assumption that successful change is achievable when common information flows both along the information continuum and amongst all levels of the information triangle. The information flow model integrates Iveroth's commonality dimensions with steps of Kotter's model pertinent to guiding coalitions, communication, and empowerment while being flexible enough to address the ideas of improvisational change.

Providing data or information within a level creates common ground. Similarly, common ground is derived from a well-integrated guiding coalition. The coalition is the most important group of messengers of the change vision and therefore, to be effective it should consist of members among all levels of the triangle. Because the guiding coalition has involvement of all information levels, when vision begins to be implemented in the firm the members of the coalition become the messengers to each of their respective levels.

Knowledge stems from the integration of information from the operational level and the vision of the strategic level. This knowledge between tactical and operational levels creates common meaning for the firm and it is the responsibility of the tactical level to serve as translators of this common meaning to the operational level. From a leadership perspective (Clawson) this part of the model exemplifies the cornerstones of level 2 leadership techniques rooted in conscious, rational, logical thought that intentionally designs and improves the structures and systems of an organization.

Wisdom is based in the vision and mission of the strategic level. Common interest is the critical piece of vision because it seeks to align various stakeholders in the firm whom tend to have differing initial interests. It is the responsibility of the strategic level to embody the common interest of the guiding coalition and align the organization to successfully achieve change. From a leadership perspective, the most successful integration of wisdom, vision, and mission are realized using level 3 leadership techniques (Clawson) based on recognizing that 
people within and external to companies have differing values, assumptions, beliefs, and expectations regarding how the way the world, the company, the project should be/is.

Common, consistent behavior is the stabilizing activity which comes as Kotter suggests at the end of a change initiative. "Culture changes only after you have successfully altered people's actions, after the new behavior produces some group benefit for a period of time, and after people see the connection between the new actions and the performance improvement." (Kotter) Common behavior spans the levels and insures that everything settles into the new patterns of behavior, although it must be initiated from the top level and should permeate the entire company. Behavior in this context must be defined by visible actions denoted as a level 3 leadership technique of exemplifying the organizational culture, commonly held values, and shared operating principles.

\section{Model Validation Results}

Validation of the accuracy and philosophy of Information Flow model was accomplished using structured interviews with director level and above personnel from diverse industries. A small strategic sample size of three interviews in three distinct industries was completed -- a President and Medical Director of a regional hospital, a Vice President of Engineering at a Unmanned Aircraft System Department of Defense commercial company, and a Director of Strategy and Planning at a multinational banking institution. Each interviewee had recently engaged his/her organization in one or more significant change projects spanning multiple functional areas within the organization. For a generalized summary of interview responses, refer to Appendix A.

Validation of need for common information flow:

All interviewees considered information flow to be important in the change management process but in varying degrees. Based on ranking of responsibilities and answers to interview questions respondents agreed that the need for common information flow is more critical for companies which are in the midst of change initiatives which span three or more functional areas. Further these change agents who ranked the need for common information flow as high also stressed using local change agents as the medium for communicating that common information. Change agents from the strategic level used tactical and operational level communicators to optimize information flow and the effectiveness of change. Finally, the interviewees indicated that common information flow is affected by the amount of technology being used to make decisions. In general, companies using more technology and information to drive decision making do so not because they have poor or inexperienced leadership or visionaries, but because there are simply too many moving parts for a few to holistically manage. The technology supports local information flow and commonality.

Validation of integrated, multi-level common ground:

All interviewees considered multilevel coalitions to be central in having a successful change initiative. All agreed that the vision of a change originates in the guiding coalition and as one interviewee put it "local leaders disciple to the people in their respective areas the vision of our change." Additionally, all interviewees ranked "communicating change initiative initiatives" in the top half of their roles as a change agent.

Validation of common meaning:

This aspect of the model was not explored in detail by any of the interviewees. It is unclear whether the questions asked did not help to facilitate this area of conversation or whether this area of the model simply is not accurate or crucial to successful change. One item in the future to consider would be to interview someone who is high in the operational level and who daily lives on the border between tactical and operational levels. It is also possible that common meaning may, in fact, not be appropriately placed within the hierarchical model. Common meaning, similar to common ground, may be more appropriately placed at a global level and not wedged between specific levels of an organization.

Validation of common interest: 
All interviewees without prompting mentioned the key words vision and mission. All communicated that the vision of the organization was always revisited for relevance or used to support the nature of the of the change initiative. One interviewee felt that, "Vision needs to be spelled out so that implementation can be derived from it." Mission for two of the interviewees seemed to be a focus of their cross-functional change initiatives. These change initiatives were very large and were rooted in changing the culture of their organizations to meeting the changing needs of their end users and the constraints of government regulations. The responses indicate that the medical and the multinational banking industries are focused on closing the gap between who they are today and what their enduser communities need. Similarly, these fields are highly affected by government regulation; integrating new regulations into the vision and mission of the industries is proving to be a charged, dynamic exercise in coming to common interest.

Validation of common behavior:

All interviewees alluded to common behavior being the end recognition of a successful change initiative. The examples of successful changes showed lasting cultural behavior shifts to self-initiated cost reduction, more open communication (positive and negative criticism) lines among the organizational levels, and a more consistent recognition that technology has flaws and those flaws need action plans to correct. In retrospect, a more accurate validation of the common behavior portion of the model would be to interview lower level personnel and use the examples provided by the change agents interviewed here and see if there is a correlation between the responses.

\section{CONCLUSION}

Overall, the information flow model has external and face validity in its content. The interview responses and content show that commonality and involvement of the entire organizational structure are critical to successful change initiatives. Further, that commonality includes the ability for open, honest discussions of alternatives and differing approaches. The interviewees also validated that accuracy, timeliness, and mechanistic flow of information is critical in having successful change initiatives.

Future analyses of change management philosophies should take a deeper look into the following aspects of information flow and change management:

- The impact of improvisational change. It is apparent that improvisational change is not something typically associated with long-lasting focused change initiatives. Is improvisational change something entirely different in focus that the traditional change management philosophy or is there something misunderstood? The placement of common meaning within the hierarchical structure. As previously mentioned, more exploration in this aspect of the commonality model and its relationship within an organization need to be done.

\section{AUTHOR INFORMATION}

Ellen D. Hoadley, Ph. D., is Professor of Management Information Systems at Loyola University Maryland where she has taught since 1988. Dr. Hoadley teaches Information Technology and Strategy in the MBA and Executive MBA programs, as well as Systems Analysis and Design at the undergraduate level. Her research areas include business process reengineering, requirements determination in systems analysis, and the use of color in the human/computer interface. Dr. Hoadley has published in journals such as Communications of the ACM, Journal of Business and Economic Perspectives, and Journal of Knowledge and Process Management. E-mail: ehoadley@loyola.edu. Corresponding author.

Jennifer J. Lamos is a 2011 graduate of the Loyola University of Maryland MBA program where she conducted the work for this paper as part of a research project with Dr. Hoadley. Ms. Lamos received undergraduate degrees in Mechanical Engineering and Bio-Resources Engineering from the University of Maryland, College Park, in 2007. Currently, Ms. Lamos is employed by AAI Corporation a subsidiary of Textron System as a Systems Engineer in the Unmanned Aircraft Systems division. E-mail: jjlamos@loyola.edu 


\section{REFERENCES}

1. $\quad$ Ackoff, R. L. "From Data to Wisdom." Journal of Applied Systems Analysis. Volume 16. (1989)

2. Anthony, R. Planning and Control Systems: A Framework for Analysis. Boston: Graduate School of Business Administration, Harvard University (1965)

3. $\quad$ Beer, Michael, Russell Eisenstat, and Bert Spector. "Why Change Programs Don't Produce Change." Harvard Business Review. Nov-Dec. (1990)

4. $\quad$ Clawson, James. Level Three Leadership: Getting Below the Surface. 5. Boston: Prentice Hall, 2011.

5. Hoadley, Ellen. "GB704.62 - Session1: Introductions and Expectations What is Information and Why Do We Care?." Loyola University, Timonium. 9/8/2010.

6. Hofman, J. and Wanda Orlikowski. "An Improvisational Model for Change Management: The Case of Groupware Technologies." Sloan Management Review. Winter. (1997)

7. Iveroth, Einar. "Inside Ericsson: A Framework for the Practice of Leading Global IT-Enabled Change." California Management Review. 53.1 (2010)

8. Kotter, John. Leading Change. Boston: Harvard Business Review Press, 1996. 
APPENDIX A

Interview Response Summary

\begin{tabular}{|c|c|c|c|}
\hline Industry & Regional For Profit Hospital & $\begin{array}{c}\text { Commercial Unmanned Aircraft } \\
\text { System }\end{array}$ & Multinational Banking \\
\hline Title & $\begin{array}{l}\text { President and Medical } \\
\text { Director }\end{array}$ & Vice President of Engineering & $\begin{array}{l}\text { Director, Strategy \& } \\
\text { Planning }\end{array}$ \\
\hline Questions & \multicolumn{3}{|l|}{ Generalized Responses } \\
\hline $\begin{array}{l}\text { 1. Please describe your } \\
\text { enterprise, major } \\
\text { products/services } \\
\text { provided, and where the } \\
\text { majority of your } \\
\text { products/services reside in } \\
\text { the life cycle. }\end{array}$ & $\begin{array}{l}\text { Multi-specialty physician } \\
\text { group. Direct patient medical } \\
\text { care. All age groups. }\end{array}$ & $\begin{array}{l}\text { Unmanned Aircraft systems market. } \\
\text { Prime commercial contractor for } \\
\text { DOD. Work covers development, } \\
\text { production and sustainment and } \\
\text { services. }\end{array}$ & $\begin{array}{l}\text { Multinational banking } \\
\text { industry covering } \\
\text { personal, commercial, } \\
\text { and institutional } \\
\text { banking and } \\
\text { investments }\end{array}$ \\
\hline $\begin{array}{l}\text { 2. How would you define } \\
\text { change management? }\end{array}$ & $\begin{array}{l}\text { Help an organization clarify } \\
\text { what it is they want to do. } \\
\text { Develop a plan to implement } \\
\text { the change desired, metrics, } \\
\text { and time line to assess the } \\
\text { success of the anticipated } \\
\text { change. }\end{array}$ & $\begin{array}{l}\text { Change management involves } \\
\text { conceiving and inserting new people, } \\
\text { processes, facilities, tools and } \\
\text { technologies through carefully } \\
\text { managed and measured initiatives to } \\
\text { achieve improved safety, quality, on- } \\
\text { time delivery, inventory control and } \\
\text { productivity in Engineering. Change } \\
\text { management is introducing a cultural } \\
\text { change in the behavior of an } \\
\text { organization and in individuals } \\
\text { within the organization to achieve an } \\
\text { end goal. I like to introduce change } \\
\text { that can be measured to reinforce the } \\
\text { positive effects of change. }\end{array}$ & $\begin{array}{l}\text { Getting people to buy } \\
\text { into a vision for an } \\
\text { enterprise }\end{array}$ \\
\hline $\begin{array}{l}\text { 3. What is your specific } \\
\text { role with change } \\
\text { management in your } \\
\text { enterprise? }\end{array}$ & $\begin{array}{l}\text { Visionary. Sponsor for } \\
\text { change. Sustaining change } \\
\text { agent. }\end{array}$ & $\begin{array}{l}\text { Champion of our many initiatives in } \\
\text { engineering, be they specifically } \\
\text { defined goals that are flowed down } \\
\text { through the organization or green } \\
\text { belt and black belt initiatives that are } \\
\text { formulated through studies. }\end{array}$ & $\begin{array}{l}\text { Strategy and planning } \\
\text { the execution of that } \\
\text { strategy. Strategy } \\
\text { should be aligned with } 5 \\
\text { year plan. }\end{array}$ \\
\hline $\begin{array}{l}\text { 4. What are the annual } \\
\text { revenues of your } \\
\text { enterprise? }\end{array}$ & $\$ 1 \mathrm{M}$ to $\$ 100 \mathrm{M}$ & $\$ 100 \mathrm{M}$ to $\$ 1 \mathrm{~B}$ & $>\$ 50 \mathrm{~B}$ \\
\hline $\begin{array}{l}\text { 5. What are the annual } \\
\text { capital and operational } \\
\text { expenditures in your } \\
\text { enterprise for_change } \\
\text { management } \text { or change } \\
\text { initiatives? }\end{array}$ & $\$ 50 \mathrm{~K}$ to $\$ 200 \mathrm{~K}$ & $>\$ 1 \mathrm{~B}$ & $>\$ 1 \mathrm{~B}$ \\
\hline $\begin{array}{l}\text { 6. How is change } \\
\text { managed within your } \\
\text { enterprise? }\end{array}$ & $\begin{array}{l}\text { Visionary group or individual, } \\
\text { Board of directors buy in with } \\
\text { all the steps needed. } \\
\text { Education about need for } \\
\text { change. Financial } \\
\text { reconciliation with the vision. } \\
\text { Analysis of whether or not the } \\
\text { change is right, needed or will } \\
\text { be accepted. "Stamp out the } \\
\text { fires that are typical triggers" } \\
\text { Our current project is very } \\
\text { well planned with specific } \\
\text { time driven steps as we are } \\
\text { changing our culture }\end{array}$ & $\begin{array}{l}\text { There are various triggers including } \\
\text { customer driven, based on root cause } \\
\text { analysis on defects in our execution, } \\
\text { self-assessment and identification of } \\
\text { gaps or weaknesses in personnel, } \\
\text { process, facilities, tools, and } \\
\text { technology, and from strategic } \\
\text { planning and operational planning } \\
\text { process initiate change to meet } \\
\text { business goals. }\end{array}$ & $\begin{array}{l}\text { Formal committees. } \\
\text { Multileveled focused } \\
\text { groups. Change } \\
\text { initiatives are derived } \\
\text { from execution } \\
\text { problems, market } \\
\text { research findings, and } 5 \\
\text { year strategic plan }\end{array}$ \\
\hline
\end{tabular}




\begin{tabular}{|c|c|c|c|}
\hline Industry & Regional For Profit Hospital & $\begin{array}{c}\text { Commercial Unmanned Aircraft } \\
\text { System }\end{array}$ & Multinational Banking \\
\hline Title & $\begin{array}{l}\text { President and Medical } \\
\text { Director }\end{array}$ & Vice President of Engineering & $\begin{array}{l}\text { Director, Strategy \& } \\
\text { Planning }\end{array}$ \\
\hline $\begin{array}{l}\text { 7. How does change } \\
\text { management interact with } \\
\text { the organizational } \\
\text { structure of the enterprise? }\end{array}$ & $\begin{array}{l}\text { Daily participation in all of our } \\
\text { planning sessions. Initially it } \\
\text { was separate before we rolled } \\
\text { it out to the rest of the } \\
\text { organization. New mission } \\
\text { statement. We identified } \\
\text { people who we knew shared } \\
\text { our vision. We moved them } \\
\text { within the company into } \\
\text { positions to perform specific } \\
\text { roles in the change. We } \\
\text { called this group the Visionary } \\
\text { committee -- "sponsors " } \\
\text { We then developed a group of } \\
\text { "local leaders" that worked in } \\
\text { their areas. We worked one on } \\
\text { one with them to develop and } \\
\text { "enroll them" in the change. } \\
\text { These local leaders disciple to } \\
\text { the people in their respective } \\
\text { areas the vision of our change. }\end{array}$ & $\begin{array}{l}\text { Continuous Improvement. } \\
\text { Framework of SIOP or VSIP or a } \\
\text { green or black belt program to } \\
\text { address specific issues ensures we } \\
\text { are not doing CI for CI's sake but it } \\
\text { is within the DNA of the business. } \\
\text { We have various groups at various } \\
\text { levels that work analysis of current } \\
\text { people and functions and } \\
\text { implementation of changes required } \\
\text { to correct defects, improve } \\
\text { efficiency, address customer } \\
\text { requirements or all of these. }\end{array}$ & $\begin{array}{l}\text { Interacts using formal } \\
\text { committees to bring } \\
\text { product lines together. } \\
\text { This includes regional, } \\
\text { national, and } \\
\text { international aspects of } \\
\text { the organizational } \\
\text { structure. }\end{array}$ \\
\hline $\begin{array}{l}\text { 8. As someone supporting } \\
\text { change management in } \\
\text { your enterprise, what are } \\
\text { your responsibilities? } \\
\text { (Rank order your roles } \\
\text { from 1- Least Central to } \\
\text { the Job to } 5 \text { - Most Central } \\
\text { to the Job) }\end{array}$ & & & $\begin{array}{l}\text { No ranking completed } \\
\text { but expressed that } \\
\text { vision, and integrating } \\
\text { applications to provide } \\
\text { efficient and accurate } \\
\text { information flow was } \\
\text { crucial. }\end{array}$ \\
\hline $\begin{array}{l}\text { Providing vision for } \\
\text { change initiative }\end{array}$ & 5 & 5 & \\
\hline $\begin{array}{l}\text { Provide/reorganize } \\
\text { resources to execute } \\
\text { change initiatives }\end{array}$ & 3 & 4 & \\
\hline $\begin{array}{l}\text { Provide budget to } \\
\text { execution of change } \\
\text { initiatives }\end{array}$ & 2 & 2 & \\
\hline $\begin{array}{l}\text { Making information } \\
\text { available for decision- } \\
\text { making in the enterprise }\end{array}$ & 4 & 1 & \\
\hline $\begin{array}{l}\text { Communicating change } \\
\text { initiative objectives }\end{array}$ & 5 & 3 & \\
\hline $\begin{array}{l}\text { Developing the } \\
\text { Developing the technology } \\
\text { infrastructure of the } \\
\text { enterprise }\end{array}$ & 2 & & \\
\hline $\begin{array}{l}\text { Integrating the } \\
\text { applications of the } \\
\text { enterprise internally and } \\
\text { externally }\end{array}$ & 5 & & \\
\hline $\begin{array}{l}\text { Innovating the enterprise } \\
\text { strategy using information } \\
\text { and technology }\end{array}$ & 5 & & \\
\hline & & & \\
\hline
\end{tabular}




\begin{tabular}{|c|c|c|c|}
\hline Industry & Regional For Profit Hospital & $\begin{array}{c}\text { Commercial Unmanned Aircraft } \\
\text { System }\end{array}$ & Multinational Banking \\
\hline Title & $\begin{array}{c}\text { President and Medical } \\
\text { Director }\end{array}$ & Vice President of Engineering & $\begin{array}{c}\text { Director, Strategy \& } \\
\text { Planning }\end{array}$ \\
\hline $\begin{array}{l}\text { 9. Describe the types of } \\
\text { change initiatives you are } \\
\text { currently involved in } \\
\text { within the enterprise. }\end{array}$ & $\begin{array}{l}\text { Change from individual single } \\
\text { specialty private practices to } \\
\text { multi-specialty group } \\
\text { practices. Change from private } \\
\text { physicians to all employed } \\
\text { physicians. Change all } \\
\text { physician employment } \\
\text { contracts to support our new } \\
\text { mission statement. Change } \\
\text { from paper Medical records to } \\
\text { an electronic medical record at } \\
\text { an enterprise level. Change } \\
\text { the culture of our practices } \\
\text { from transactional medicine to } \\
\text { a preventive model. Change } \\
\text { culture from "I" to "we" and } \\
\text { "my" to "our." For example, } \\
\text { "my bottom line" to "our } \\
\text { bottom line." }\end{array}$ & $\begin{array}{l}\text { - Improving Systems Engineering } \\
\text { practices in requirements based } \\
\text { design, requirements development } \\
\text { and management, including } \\
\text { implementing a process for } \\
\text { Requirements Change Review } \\
\text { Boards and making System Function } \\
\text { Reviews a baseline in our design } \\
\text { process where it has not been in the } \\
\text { past. } \\
\text { - Improving Configuration } \\
\text { Management practices to better } \\
\text { coordinate and synchronize ECNs } \\
\text { and ECPs to the bi-annual release of } \\
\text { technical manual updates mandated } \\
\text { by our customer } \\
\text { - Implementing Design Standards in } \\
\text { specific engineering hardware efforts } \\
\text { such as grounding and shielding, } \\
\text { circuit board design, mechanical } \\
\text { assembly Design-for X practices, } \\
\text { structural and aerodynamic design, } \\
\text { propulsion and fuel system design } \\
\text { and avionics design. } \\
\text { - Improving the Test process and } \\
\text { early involvement of test engineering } \\
\text { in our designs. } \\
\text { - Achieving CMMI level } 3 \text { minimum } \\
\text { with a goal for level } 5 \text { in systems, } \\
\text { hardware, and program management } \\
\text { (we are already level } 5 \text { in Software). }\end{array}$ & $\begin{array}{l}\text { No specifics given. IP } \\
\text { claimed. }\end{array}$ \\
\hline $\begin{array}{l}\text { 10. What is the } \\
\text { breakdown of change } \\
\text { initiatives in your } \\
\text { enterprise? Use } \\
\text { percentages. }\end{array}$ & & & $\begin{array}{l}\text { No specific break down } \\
\text { given but implied that } \\
\text { medium and large were } \\
\text { largest focus for her } \\
\text { level of management. }\end{array}$ \\
\hline $\begin{array}{l}\text { Small change initiatives } \\
\text { (less than } 30 \text { days) }\end{array}$ & 20 & 25 & \\
\hline $\begin{array}{l}\text { Medium change initiatives } \\
\text { ( } 30 \text { days to } 6 \text { months) }\end{array}$ & 45 & 55 & \\
\hline $\begin{array}{l}\text { Large change initiatives ( } 6 \\
\text { months or greater) }\end{array}$ & 35 & 20 & \\
\hline Within one functional area & & 40 & $\begin{array}{l}\text { No specific answer but } \\
\text { implied that among 2-3 } \\
\text { was the major focus } \\
\text { area. Specifically IT } \\
\text { was a focus within } \\
\text { many initiatives. }\end{array}$ \\
\hline $\begin{array}{l}\text { Among 2-3 functional } \\
\text { areas }\end{array}$ & 10 & 50 & \\
\hline $\begin{array}{l}\text { Among } 3 \text { or more } \\
\text { functional areas }\end{array}$ & 90 & 10 & \\
\hline
\end{tabular}




\begin{tabular}{|c|c|c|c|}
\hline Industry & Regional For Profit Hospital & $\begin{array}{c}\text { Commercial Unmanned Aircraft } \\
\text { System }\end{array}$ & Multinational Banking \\
\hline Title & $\begin{array}{c}\text { President and Medical } \\
\text { Director }\end{array}$ & Vice President of Engineering & $\begin{array}{c}\text { Director, Strategy \& } \\
\text { Planning }\end{array}$ \\
\hline $\begin{array}{l}\text { 11. Describe a successful } \\
\text { change initiative you have } \\
\text { been involved with and } \\
\text { explain why you think it } \\
\text { was successful? }\end{array}$ & $\begin{array}{l}\text { See } \# 9 . \text { These are all on } \\
\text { schedule ......lots of planning } \\
\text { and being sure we involved all } \\
\text { local leaders in the change } \\
\text { process... Mistakes in the } \\
\text { process of change are } \\
\text { discussed openly without risks } \\
\text { of job etc.... See number } 2\end{array}$ & $\begin{array}{l}\text { When we initially fielded the } \\
\text { Shadow System our approach was to } \\
\text { be very conservative on quantities of } \\
\text { spares ordered and maintained in } \\
\text { stock. This led to very good } \\
\text { availability but drove costs very high. } \\
\text { We undertook an initiative to drive } \\
\text { the average repair turn-around time } \\
\text { down by a significant amount (a } \\
\text { factor of } 3 \text { over } 3 \text { years). This was } \\
\text { accomplished through subcontractor } \\
\text { incentives and absolute dedication to } \\
\text { execution. In } 2005 \text { our average } \\
\text { annual sustainment costs were } \\
\text { approximately } 15-16 \% \text { of the } \\
\text { procured system value per year in a } \\
\text { developing war. In } 2010 \text { our average } \\
\text { annual total sustainment cost had } \\
\text { dropped to less than } 5 \% \text { of the } \\
\text { procured system value per year. We } \\
\text { received the OSD PBL award for } \\
\text { Systems and the industry award for } \\
\text { Logistics in } 2010 \text {. }\end{array}$ & $\begin{array}{l}\text { No specifics given. IP } \\
\text { claimed. }\end{array}$ \\
\hline $\begin{array}{l}\text { 12. Describe an } \\
\text { unsuccessful change } \\
\text { initiative you have been } \\
\text { involved with and explain } \\
\text { why you think it was } \\
\text { unsuccessful and what you } \\
\text { would do differently in } \\
\text { retrospect? }\end{array}$ & $\begin{array}{l}10 \text { years ago, tried to build a } \\
\text { small multispecialty group into } \\
\text { a much larger group....I did not } \\
\text { understand the ideas of } \\
\text { enrollment, local leadership, } \\
\text { metrics, absolute consistency } \\
\text { in message, absolute financial } \\
\text { consistency. The leader } \\
\text { cannot do it alone... Always } \\
\text { ask the people doing the job } \\
\text { how it could be done } \\
\text { better.......give credit to all } \\
\text { involved..... The Leadership } \\
\text { must take the blame for } \\
\text { problems with implementation } \\
\text { and realization of vision not } \\
\text { the rest of the employees... }\end{array}$ & $\begin{array}{l}\text { One of the initiatives that we } \\
\text { undertook upon the reorganization of } \\
\text { engineering was to try to be very } \\
\text { specific about what each individual's } \\
\text { role, responsibility, authority and } \\
\text { accountability were and who did } \\
\text { their review and their time card. The } \\
\text { original concept was to create a work } \\
\text { assignment form that would record } \\
\text { all of this information and place this } \\
\text { into a database. A form and database } \\
\text { was created and rolled out in a } \\
\text { benchmark, but did not gain } \\
\text { acceptance because it replicated } \\
\text { information that was in (or should } \\
\text { have been in) the PMP used to record } \\
\text { what each person's goals were for the } \\
\text { year. After some discussion with the } \\
\text { constituents it was decided that what } \\
\text { we needed was better quality PMPs } \\
\text { rather than a new database and form. } \\
\text { The key was that the change was } \\
\text { needed but the root cause of the lack } \\
\text { of direction fell into other areas and } \\
\text { it was more efficient and effective to } \\
\text { fix them rather than band-aid the } \\
\text { situation. }\end{array}$ & $\begin{array}{l}\text { No specifics given. IP } \\
\text { claimed. }\end{array}$ \\
\hline
\end{tabular}


\begin{tabular}{ll} 
International Journal of Management \& Information Systems - First Quarter $2012 \quad$ Volume 16, Number 1 \\
\hline
\end{tabular} NOTES 